\title{
TWO MANHATTAN LAND PAPERS OF THE SEVENTEENTH CENTURY
}

\author{
BY VICTOR HUGO PALTSITS
}

When in 1941 Dr. Paltsits retired from his position as chief of the American History Division in the New York Public Library, those interested in American historical scholarship might have assumed that a great career had ended. Indeed, such would have been true of most men, but for this devoted scholar the relief from regular employment merely served as an opportunity for further research and writing. The two documents which are described in this paper were presented to the Rutgers University Library by Dr. Paltsits, who holds the degree of Doctor of Letters, honoris causa, from Rutgers.

$\mathrm{R}$

ECENTLY acquired by the Library are two land documents relating to Rutger Jacobsen, progenitor of the Rutgers family of New Netherland and New York. Since Rutger was a collateral ancestor, so to speak, of Rutgers University, a short account of him and of the two papers in which his name appears may be of some interest.

Rutger Jacobsen of Schoenderwoerdt embarked from the Texel, Holland, on October I, I636, in the vessel Rensselaersweyck, Jan Tiebkins, schipper, bound for Fort Orange (now Albany), in New Netherland, in the service of the first Patroon, Kiliaen van Rensselaer. His native heath, Schoenderwoerdt, was "a pretty Dutch village, two miles from Vianen, where Van Rensselaer had a country seat." ${ }^{1}$

At Rensselaerswyck "Rutger became a man of considerable repute and wealth." He married in June, I646, in New Amsterdam, Trijntje (Catharine) Jansse van Breestede. Three years later he became a brewer in Rensselaerswyck. In I 654 his brewery was on what is now Beaver Street. He was also a shipper of beaver skins, and owned a sloop on the river. He speculated in building lots in the village of Fort Orange and in farming land nearby. By $\mathrm{I} 66 \mathrm{I}$ he owned a share in Mohicander's Island.

His name, Rutger Jacobsen, means that his given name was

1 These and other data about him are garnered from Ernest H. Crosby, "The Rutgers Family of New York," New York Genealogical and Biographical Record, Vol. 17 (April, 1886), pp. 82-93. 
Rutger and that he was the son of Jacob. There was then no patronymic. That came from his son Harman Rutgers (or Rutgersen); that patronymic is derived from then on. But there were some lines that adopted as a patronymic the form "van Woerdt," a contraction of the village name "van Schoenderwoerdt," the place of origin of Rutger Jacobsen. He, the progenitor, remained in Rensselaerswyck, where he died in I 665, survived by a wife and three children, namely: Margaret, who was married to Jan Jansen Bleecker, the ancestor of the Bleecker family; Engeltje is said to have been married to Melgert Abrahamsen van Deusen; and an only son, Harman, above named, who created the patronymic of Rutgers. This son was also a brewer and had New Amsterdam interests.

The first of the two instruments herein described is written in Dutch. The second is a confirmation of the first by the new English governor. We shall treat them separately.

\section{I}

The first document is concerned with land on Manhattan Island in the City of New Amsterdam lying on Hoogh Straet (High Street). In it Rutger Jacobsen appears before Schepen, and makes declaration recorded in this instrument, that he, a resident of Fort Orange (now Albany), had a transport (conveyance) dated 4 October I649, and written consent of Domine Joannes Megapolensis of date I 2 November I 66I, to Sieur Johannes Withart, burger here, etc. for land lying on the north of the Hoogh Straet, beside the residence of Sieur Isaack Bedloo, surveyed by Jacques Cortelyou. ${ }^{2}$

The Schepen named in the instrument, before whom Rutger Jacobsen deposed, are Timothy Gabry and Joannes van Brugh, and reference is made to the attaching of the seal thereto, which red wax seal with the arms of New Amsterdam is perfectly preserved in an excellent impression, and is very rare in such condition. The instrument is in the handwriting of Johannes Nevius, as secretary of the City of New Amsterdam.

Joannes Nevius ( I627-I672), married Adriaentje (Bleijck) Jans. He came to America about I650, became a member of the court of

\footnotetext{
2 The place of this instrument in the history of land titles of New Amsterdam can be seen in I. N. P. Stokes, The Iconography of Manhattan Island, New York, 1915, II, 302-3, nos. 18 and 19.
} 
Burgomasters, and from I 657 to $\mathrm{I} 665$ was secretary of the City. $\mathrm{He}$ was an intelligent man and active in public affairs. He was also the first ferryman of the ferry between New Amsterdam and Breuckelen (the Brooklyn ferry). The original surname of his Holland ancestors was Neef, a family name above the commoners, which had a coat-ofarms. He used a Latinized form Nevius, as was then common for a Sieur or Yonkheer. He was the founder of the family in America. His descendants now use as a patronymic Nevius, Neafie, and other forms. ${ }^{3}$

Jacques Cortelyou, mentioned in the instruments as the surveyor of the land involved, was the ancestor of the Cortelyou family, and one of the most distinguished men of all New Netherland. He made the first detailed street survey of New Amsterdam in I660, and his plan is reproduced, and interpreted by me, in Stokes's Iconography. The neighboring residence mentioned in this instrument, of Sieur Isaack Bedloo, is a name perpetuated among us as the owner then of Bedlows Island (Love Island) in our New York harbor. So that in this instrument there are involved the names of the founders of the Rutgers, Nevius, and Cortelyou families, who have left a progeny among whom were philanthropists, statesmen, and otherwise men of mark.

\section{II}

The second document is a confirmation of the land situated on the north part of High Street, which Rutger Jacobsen had possessed and conveyed to Johannes Withart on September I2, I66I, and is by this instrument from Governor Francis Lovelace made secure for Withart, his heirs and assigns forever. Such confirmations by the English governors were required and were made possible by the surrender provisions of New Netherland in 1664, under the authority received from the Duke of York, Proprietor of the Province of New York.

A companion piece of the Nevius document of $\mathrm{I} 66 \mathrm{I}$, this confirmation was executed at Fort James (formerly called "Fort van Nieuw Amsterdam") on May I4, I670. It was written by the clerk of the province and is signed in the bold full signature of the governor,

${ }^{\mathbf{3}}$ See A. Van Doren Honeyman, Joannes Nevius . . and His Descendants, Plainfield, N.J., I 900 . 
Francis Lovelace. ${ }^{4}$ The attest by Matthias Nicolls, as provincial secretary is also interesting. He was the ancestor of the family that now spells the name Nichols. The attached paper seal is intact. It is the first seal that was used on English instruments in New York, and is often missing now from these old papers.

${ }^{4}$ See his biography in the Dictionary of American Biography, written by V. H. Paltsits, who as State Historian of New York has also edited the records of Lovelace, Minutes of the Executive Council of the Province of New York: Administration of Francis Love-

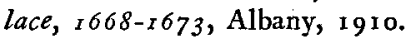




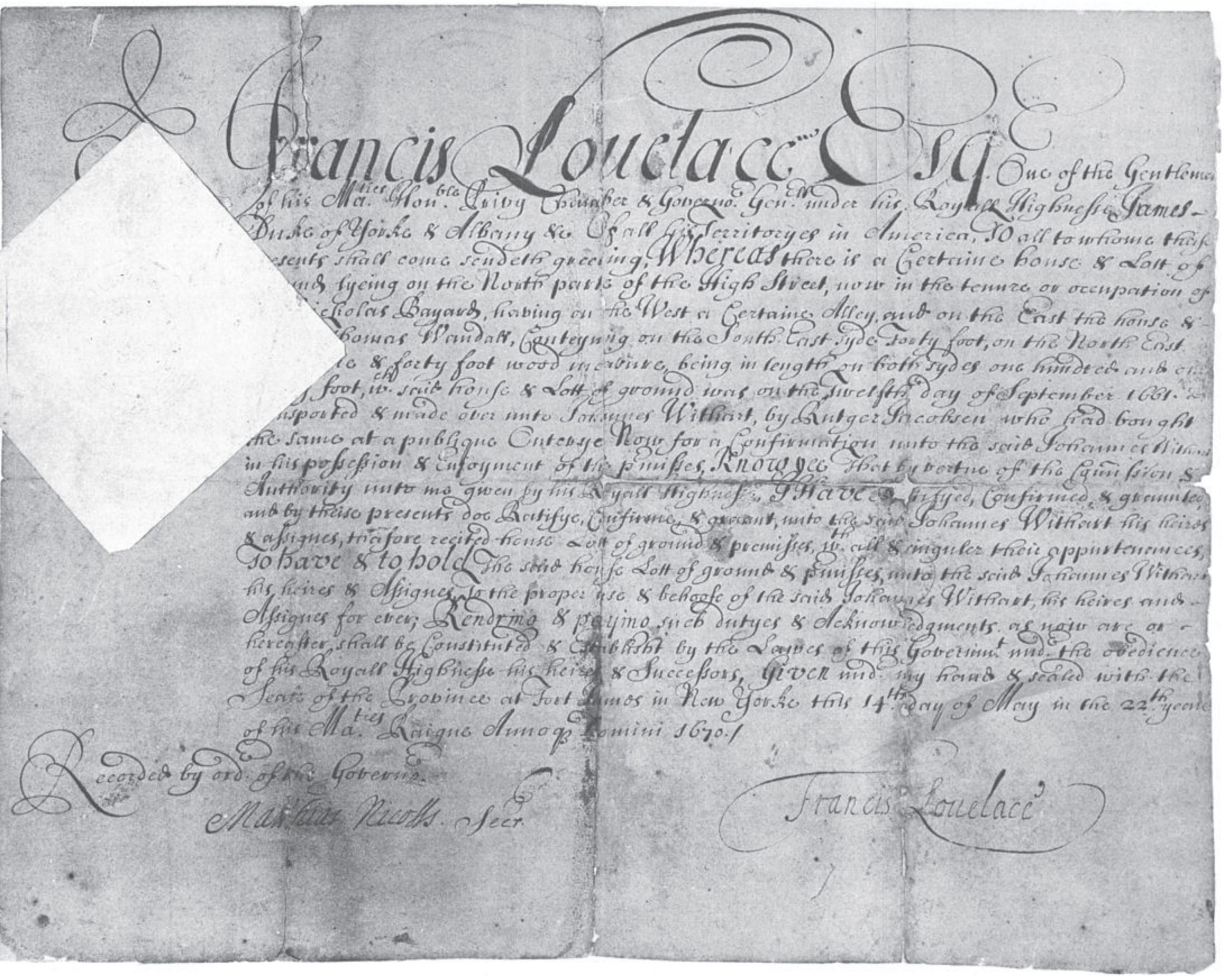

